\title{
Sea-level Correlations: Applying IGCP Results
}

\author{
by Paolo A. Pirazzoli
}

Research on changes in sea level, through the International Geological Correlation Programme and elsewhere, has had a growing impact on earth sciences in the last two decades. This article describes the origin, organization, results and follow-up of the very successful IGCP Project 200 on sealevel changes. A better understanding of the causes and process of variations in sea level now exists, though problems still remain. Indeed, the author questions the relationship between recent rises in temperature and sea levels. Current concern about the possibility of a forthcoming rise in sea level because of the increase in atmos pheric $\mathrm{CO}_{2}$ adds urgency to research efforts to model and predict sea-level variations more accurately. (Ed.)

\section{The Backg round}

Ideas on sea-level variations have evolved a long way since the dispute between R.W. Fairbridge (1961) and F.P. Shepard (1964) about the most likely shape - fluctuating or rising gradually - of the curve representing global sea-level changes during the Holocene. This debate focused the interest of many scientists on the subject and set the course a few years later for IGCP Project 61 , the aim of which was to graph globally the trend of mean sea level during the last 15,000 years. It was believed then that the occurrence of superimposed emerged marine terraces could demonstrate, especially around the Mediterranean, a gradual long-term drop in the global sea level, throughout four Quaternary glacio-eustatic fluctuations.

When IGCP 61 began in 1974 ideas of a static Earth were being completely upset, for global tectonics had shown that the crust could be much more dynamic than previously believed (Fig. 1), especially near plate boundaries. For example, accepted ideas were thrown into question by results from oxygen isotope studies of Pleistocene oceanic cores (Emiliani and Shackleton, 1974), showing that other glacial-interglacial cycles, in addition to the four main ones recognized near the Alps, had probably taken place during the Quaternary. Satellites had shown a sea-level topography deviating appreciably from a rotational ellipsoid; bumps and depressions of the ocean surface water could be explained only by density changes inside the Earth. Since such mass changes are probably on-going, here was another possible cause of vertical movements of the sea surface, previously unsuspected. Moreover, when glacio-isostatic movements were taken into account, the old notion of geoidal changes, supported anew by Mörner (1976), could no longer be disregarded.

The first compilations of worldwide sea-level data (Pirazzoli, 1976; Bloom, 1977) confirmed the existence of Holocene sea-level histories varying considerably around the world. Global isostatic models, developed by Walcott (1972) and Clark and others (1978) proposed a general explanation that glacio-isostatic movements were not only localized near former ice sheets, but that they also contributed, together with hydro-isostatic displacements in coastal areas due to melt water accessions (Bloom, 1967), to modifying sea levels throughout the globe. Although these considerations could not explain all documented changes in sea level, they helped to demonstrate that the determination of a single sea-level curve of global applicability was an illusory task and that by definition the initial goal of IGCP 61 was ill conceived.

The situation is illustrated by Figure 2, after the late W.S. Newman (personal communication, 1985). It is a plot of elevation versus time of over 4000 radiocarbon-dated indicators of sea level for the past 16,000 years, obtained from the coastal areas of many of the world's major land masses, as well as from oceanic islands. The probable magnitude of the glacio-eustatic sea-level rise is exceeded by vertical movements of land. For example, formerly glaciated areas reveal late-glacial sea levels more than $200 \mathrm{~m}$ above the contemporary datum, while zones on the margin of these glaciated areas show earlier sea levels as much as $160 \mathrm{~m}$ below the same datum. Thus the late glacial sealevel geoid now exhibits a relief of more than $360 \mathrm{~m}$, exceeding the highest estimated glacio-eustatic rise by a factor of two.

At the beginning of the IGCP successor Project 200, which began in 1983, most of these ideas had not yet been assimilated by many sea-level workers. Furthermore, immense coastal areas of the world were still, in the words of the W.S. Newman, "deserts of sea-level data." It was, thus, highly desirable to promote surveys in new areas and to continue the efforts made by IGCP 61 to improve methods of investigation, in the interests of better evaluation of scientific results and a more critical approach to the existing literature.

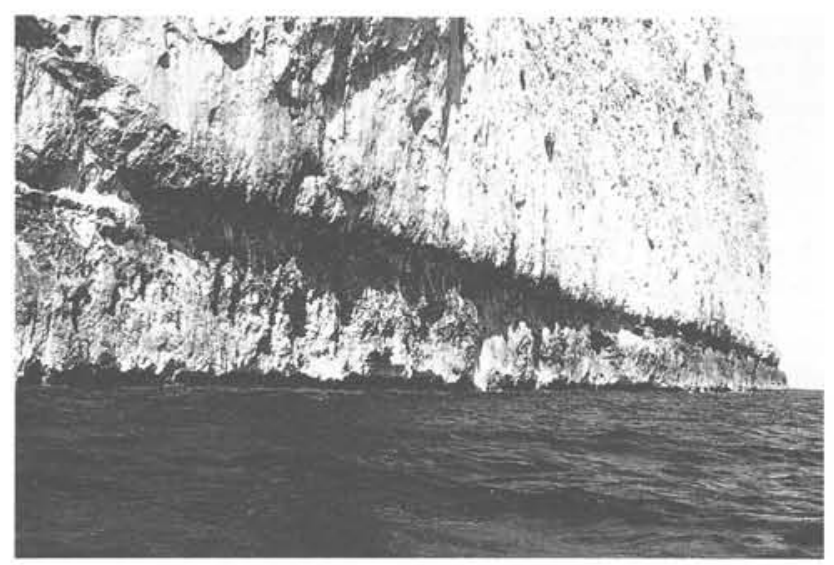

Figure 1: Marks of a sudden uplift of more than $5 \mathrm{~m}$, about 1530 years ago, are visible on the cliffs of Gramvousa Peninsula in western Crete (Greece). Evidence elsewhere has shown that a major tectonic event, the "Early Byzantine Tectonic Paroxysm," occurred at the same time over distances of $1200 \mathrm{~km}$ in the eastern Mediterranean. 
The aim by now was to determine as precisely as possible local sea-level histories, to consider all such variations as potentially influenced by a complex of local, regional and global processes, and to identify and assess internal and external effects. The ultimate purpose was to provide a basis for predicting near-future sea-level changes, especially in densely populated low-lying coastal areas (Fig. 3). what was required, therefore, was a more interdisciplinary approach to sea-level problems and an increase in international cooperation.

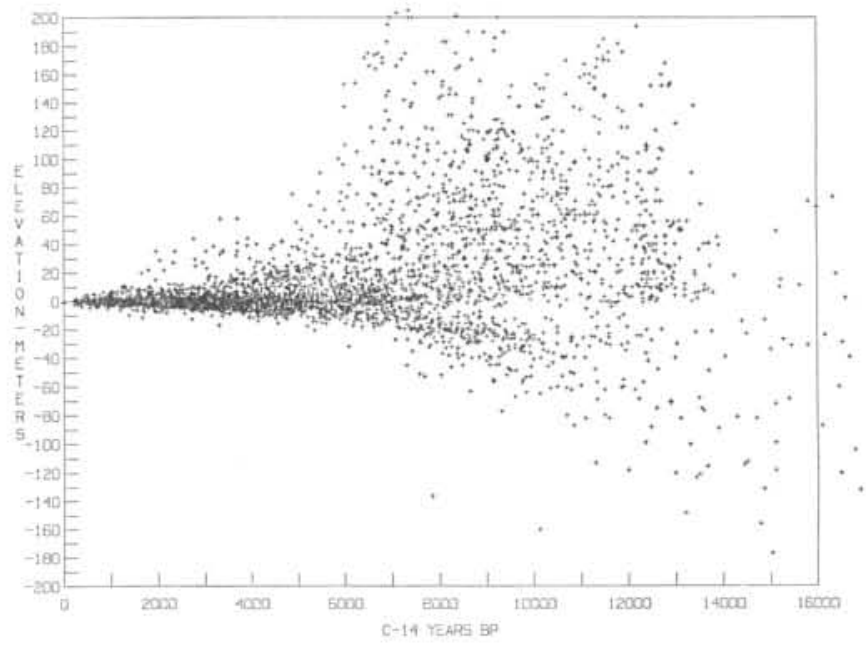

Figure 2: Elevation versus time plot of dated indicators of sea levels for the past 16,000 years. After work by W.S. Newman (personal communication, 1985).

\section{The Work of IGCP 200}

Over 600 participants from 67 countries joined IGCP 200, 33 national working groups were endorsed, and seven sea-level data banks were made available. The organization of a dozen thematic working groups favoured the development of multidisciplinary approaches. A directory of sea-level research was published and circulated in 1984, and then updated towards the end of the project (Shennan and Pirazzoli, 1987). Some 14 international sea-level meetings, five of them in the Southern Hemisphere, were organized between 1983 and 1987. Eleven of these meetings included field trips that provided good opportunities to observe and discuss field relationships (e.g. see reviews in Episodes, v. $7 / 4$, p. $37-38$; v. $8 / 3$, D. $193-195$, and v. $9 / 1$, p. $30-31)$.

Efforts to improve the quality of sea-level data and to assist researchers in developing countries have resulted in the publication of two manuals on the evaluation of geological indicators of sea levels (van de Plassche, 1986) and of tidal gauges (IOC, 1985). The proceedings of several international meetings have already been published (e.g.: Pirazzoli et al., 1985; Hopley and Pirazzoli, 1985; Davies and Montaggioni, 1985; Pirazzoli and Suter, 1986; Qin and Zhao, 1987; Carter and Devoy, 1987; Raban, 1988), and others are still in preparation. In addition, two volumes have been devoted to review and research papers (Tooley and Shennan, 1987; Devoy, 1987), and a monograph on tides, surges and mean sea level (Pugh, 1987) has also been published. Altogether the total number of publications resulting from Project 200 is estimated as over 1,000 (Pirazzoli, 1987a).

\section{New Results}

Many new results have been obtained from areas where previous coverage was insufficient, such as Argentina, China, French Polynesia, India, Indonesia, Ireland, Jamaica and Sri Lanka, and other studies have yielded more details on many regions studied earlier. This is not the place for a detailed summary of project results, but some generalizations can be made.

Une major conclusion is the confirmation, by field data and models, of the spatial variability in sea levels that had been assumed at the beginning of $1 G \mathrm{CP} 200$. This variability, which has been demonstrated, makes worldwide (eustatic) approaches unrealistic and misleading and appears to depend on a combination of factors that operate globally, regionally or locally on different time scales (e.g. Pirazzoli and Grant, 1987, and see Figs. '2, 4 and 5 ). No stable area has been recognized anywhere in the world, and similar conclusions can be extended to earlier periods of geological history (e.g. Burton et al., 1987) with radiocarbon-dated sea levels as well as tide-gauge records.

Good progress in new dating methods, such as electron spin resonance, thermoluminescence, and amino-acid racemization, has enabled Pleistocene shorelines older than the last interglacial period to be dated successfully in many parts of the world. A great improvement has been obtained in understanding the relationship between coral reef growth and the sea-level rise (e.g. Davies and Montaggioni, 19ъз). Holocene seismo-tectonic movements are now better understood especially in Japan (Fig. 6), New Zealand and the Mediterranean, and new estimates of seismic magnitude have been obtained from the height of raised shorelines and the size of the uplifted area (e.g. Kawana and Pirazzoli, 1985). A preliminary assessment of long- and short-term rates of relative vertical movements is now possiole for most of the areas studied. 'This assessment is essential for the prediction of future sea-level changes and coastal applications.

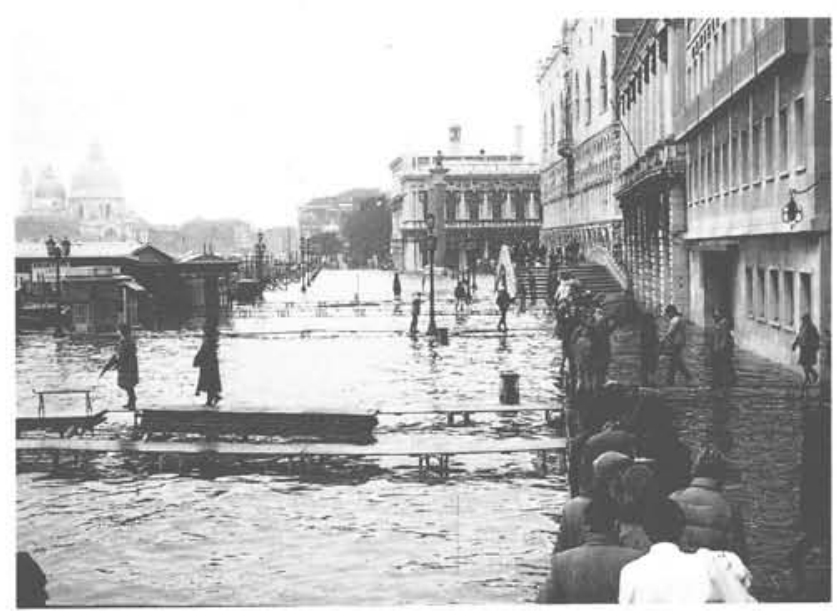

Figure 3: Venice, where human activities have caused a serious increase in the frequency of flooding during the last few decades, would be greatly endangered even by a very small rise in sea level (Pirazzoli, 1987b).

Advances have also come from exchanges between field workers and those who construct models based on tectonic processes, melting histories of major ice sheets or the volcanic or sedimentary loading of the lithosphere. The latter have suggested that variations in response to deglacial events and to changes in mantle viscosity may point to important locations for future sea-level research. Field workers are producing more details on relative sealevel histories and will, one hopes, increase knowledge of upper earth rheology and tectonic movements on which to base more sophisticated models. A similar interaction will probably develop in the future between those producing oceanographic or climatic models and those working on tidal gauge records. 


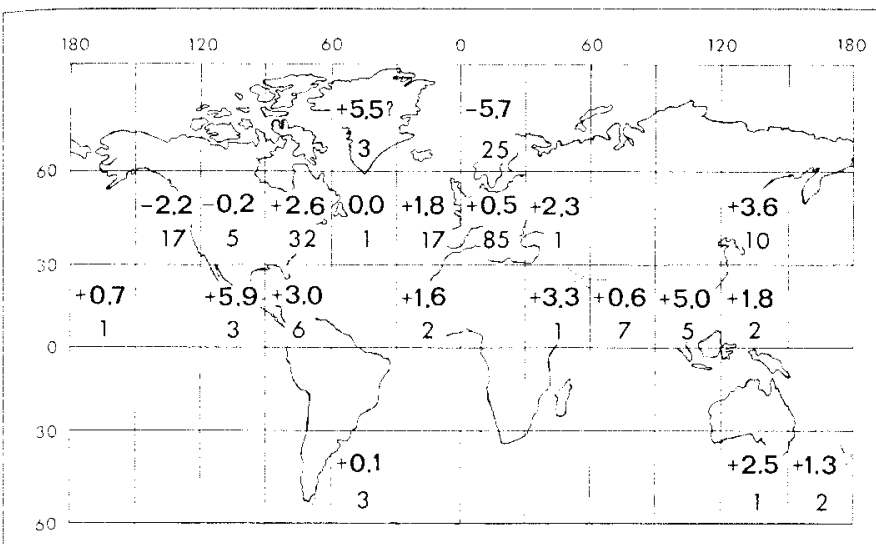

Figure 4: Long-term linear trends of relative sealevel change from tidal gauge data averaged for $30^{\circ}$ longitude compartments. Larger numbers indicate average values (in $\mathrm{mm} / \mathrm{y}$ ), and smaller numbers correspond to the number of stations used for observation in each compartment. From Pirazzoli and suter (1986).

\section{New Applications}

Applications of sea-level research were ratner new to most workers in 1983 , but since then many seeds have been sown and have germinated well. Growth is now catalytic, and many applications are beginning to be generated.

ihe most common of these is concerned with off thnore sedimentary processes, allowing the development of plans compatible with the predictable evolution of the coast, its management and defence. At a time when coasts all over the world are being more and more intensely exploited for urbanization, port facilities, and industrial and recreational development, it is important to arrive at a better understanding of the potential risks, so as to avoid repeating indefinitely the many costly errors of the past. Coastal areas are very sensitive, however, to political and economic pressures, and serious difficulties are sometimes encountered when attempting to give priority to even essential scientific recommendations.

I'he new data can also be applied to the reconstruction of late wuaternary paleoenvironments on continental shelves and to the study of placers located along submerged shorelines. New paleogeographic maps have been produced of many shelf areas, including the Wediterranean, the Black Sea, the Gulf of Hexico, eastern Canada, West Africa, the Seychelles Bank, nortnwest Madagascar, the Yellow Sea and the Aretic Sea, and maps of other areas are in preparation.

Although it is still too early to know which ideas, among the many new ones that emerged from lGive 200 , will be useful for future sea-level researen, the project certainly helped to integrate the recent results and concepts into the everyday work of an impressive number of scholars. It has also been responsible for the gathering and circulation of a great amount of new sea-level data, essential to a better evaluation of the complex causes of sea-level change. Lastly, by opening the way for applications, IGCP zUU has had a leading role in making sea-level studies more useful in the short term not only for science, but also for the enlightenment of law makers and coastal planners, while creating an overall awareness in the coastal population in general.

Among the tasks remaining to be accomplished is the elaboration of an objective, generally acceptable and universally applicable methodology, for improving correlation of sealevel data Detween regions. 1 his would require all sea-level workers to agree to the use of a standard format for evaluating their field data. Unfortunately, very few participants in such an international project spend much time on making their own data available to these data banks. In
Spite of several efforts, neither Project 61 nor 200 was able to improve this situation muen. Nevertheless, the licer Board labelled Project 200 as one of its "most fruitful; it surpassed its goal and can be considered as an exemplary one."

\section{How to Run an IGCP Project}

An IGCP Project leader is often confronted with questions such as what is the best way to set up, run and finance an international project. All these aspects are in fact closely linked, but the key factor is probably the existence of a
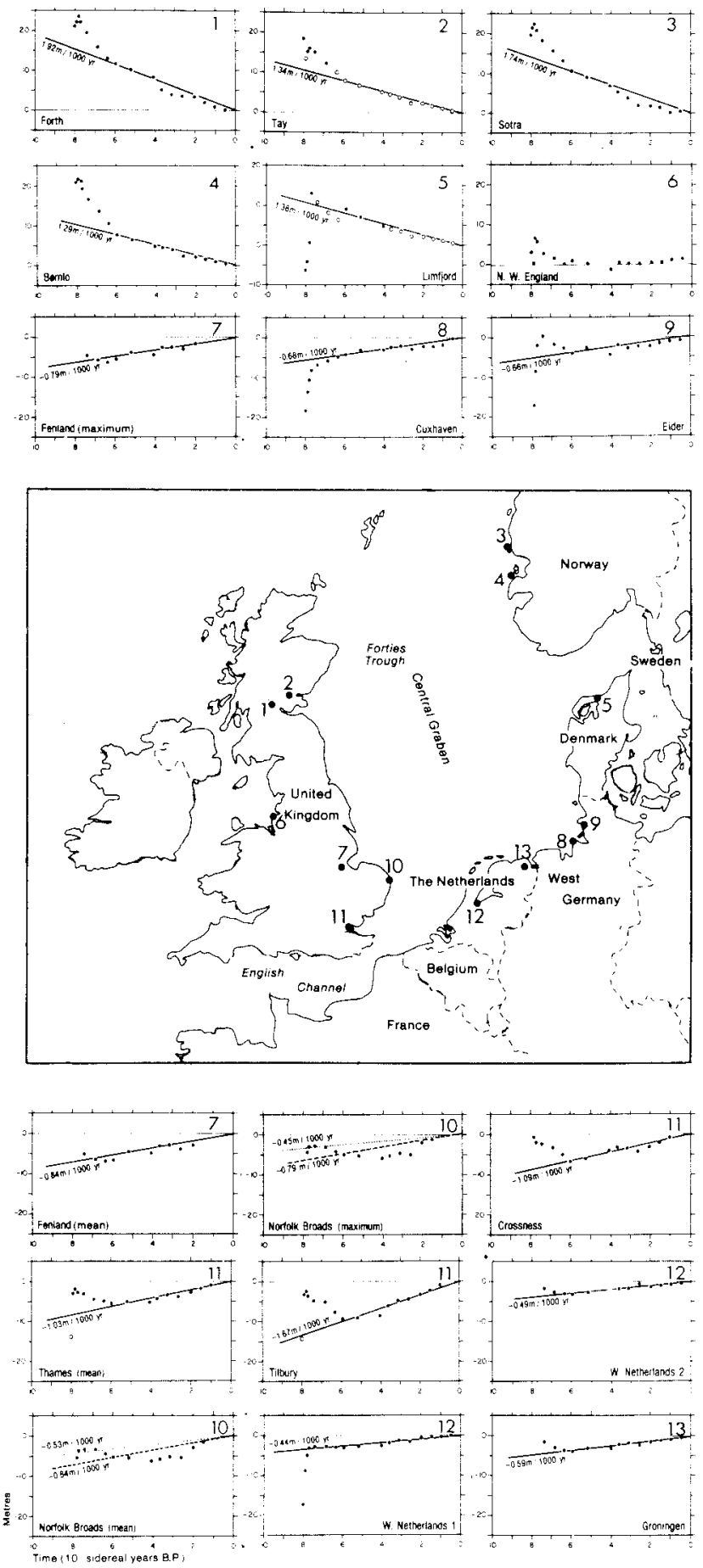

Figure 5: Computed uplift and subsidence from sites around the North Sea obtained by a comparison between Holocene sea-level curves. After Figure 4.10 of Shennan (in Tooley and Shennan, 1987). 
sufficient number of participants in the project with strong scientific motivations. It certainly helps to launch the project with a wide consultation among scientists likely to participate actively, and advance publicity and timely circulation of information are essential.

The financial arrangements should be clearly understood from the outset so as to avoid misunderstandings about possibilities of funding and time-consuming exchanges of unnecessary mail. It should be clear to everyone that Uneseo and IUGS can contribute only "seed money," usually a few thousand dollars per year, that these cannot be carried over from one year to the next, and that they must be "distributed equitably on a geographical basis" to help participants attend annual meetings. Full funding of travel and living expenses for a small number of people certainly guarantees their participation in annual meetings, but it has a very limited impact on the attendance and success of the meeting and is, therefore, not recommended.

It is preferable to divide the seed money among a larger number of applicants, even though this will limit the amount of support for each individual to only a fraction of the total expenses. Consequently, the Project leader and other keen applicants must search elsewhere for additional financial support, such as from national IGCP committees. In many cases participants use research funds from their Institute or even their personal money in order to attend. This system is, however, unfavourable to scientists from developing countries, who cannot generally attend international meetings abroad unless most of their expenses are covered.

In general, financial support is not provided either by IGCP or by IUGS to assist the actual research involved and the number of national IGCP Committees able to contribute to research activities is very small. The success of an IGCP project, therefore, depends strongly on the ability to use existing facilities, promote new funded activities or divert existing ones to aims closer to those of the project. Fortunately, the IGCP label usually guarantees internationa interest, which is important for obtaining funds. In short, scientific motivation and ability to "sell" the IGCP label effectively are two essential qualities in people responsible for coordination. Another obvious requirement is a wellbalanced, international distribution of responsibilities.

Once a project has started, clear statements should be made as to what participation entails and what kind of contribution is expected from each participant. In the case of IGCP 200 , we managed to circulate annual reports to all participants through newsletters, printing and mailing costs being assumed in turn by volunteers with facilities available in their institutes. In addition, substantial extracts of the

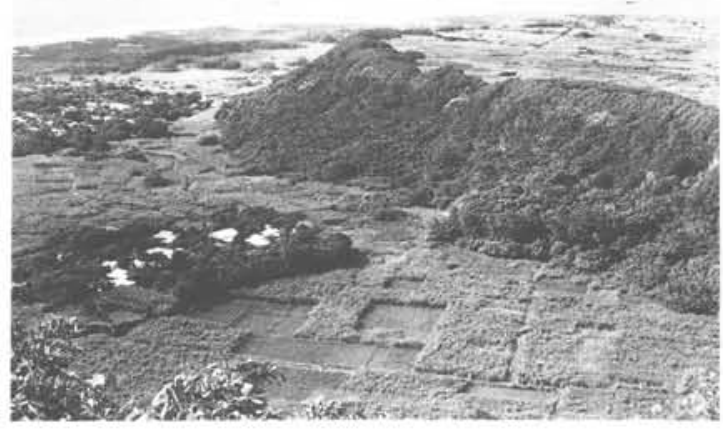

Figure 6: Marine terraces caused by a tectonic uplift near a subduction zone, Kikai Island, southwest Japan. To the right is the Kawamine terrace, 70 to $75 \mathrm{~m}$ above sea level and dated at 50 to 87 kyr. To the left is a Holocene coral reef terrace that reaches $13 \mathrm{~m}$ in altitude. The data indicate that the island is being uplifted at an average rate of 2.0 $\pm 0.5 \mathrm{mu} / \mathrm{yr}$. reports were reproduced in Geological Correlation, Journal of Coastal Research and other periodicals. The early preparation of a Directory of research workers was essential in stimulating international cooperation.

The preparátion of an international symposium and a field meeting (Fig. 7) while a heavy task for organizers, provides an excellent opportunity to make local results known to an international audience. Because appropriate funds often take a long time to secure, a preliminary calendar for meetings, evenly distributed from the geographical point of view and open to change, should be decided upon and announced well in advance. The choice between meetings organized by the project alone, or within the framework of other international activities, will obviously depend both on financial support available and on scientific interest in the area to be visited.

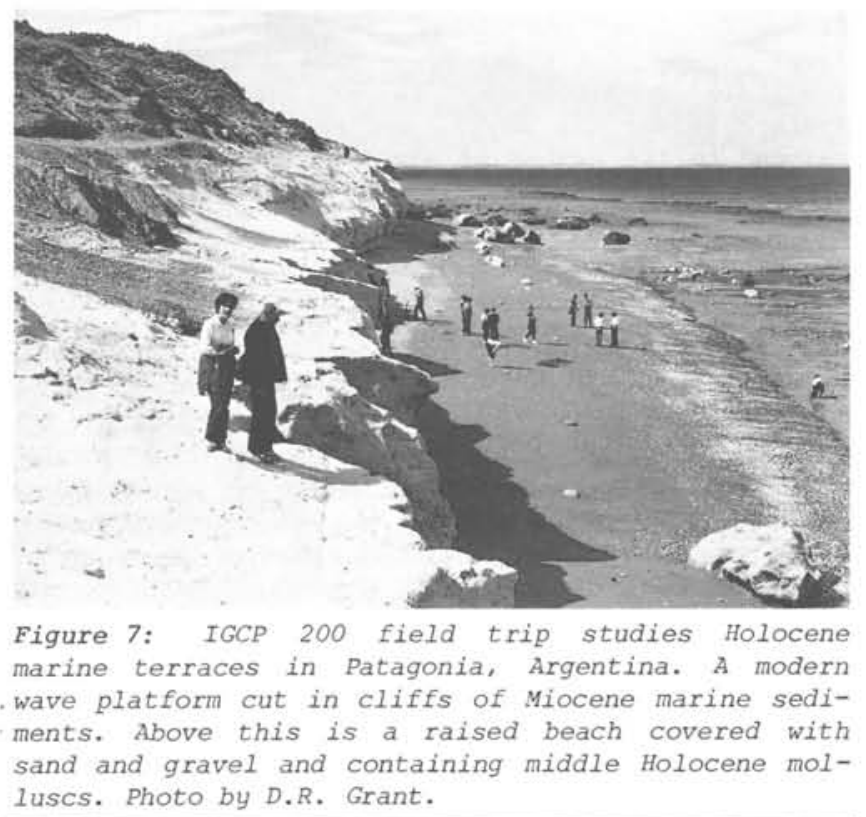

Interdisciplinary studies have been strongly encouraged by the IGCP Board in recent years. Accordingly the thematic focus of IGCP 200, as opposed to the traditional regional emphasis, worked well, though no more than one person per country could normally be supported even where there were several active working group leaders from different disciplines. In this connection IGCP 200 found some extra support through creation of official links and active collaboration with INQUA (especially its commission on shorelines and neotectonics), the Committee on Climatic Changes and the Ocean (of the Intergovernmental Oceanographic Commission and the Scientific Committee on Oceanic Research), the Permanent Service for Mean Sea Level, the Inter-Union Commission on the Lithosphere and the International Association of Geodesy.

\section{Current Projects}

Since the end of IGCP 200, two new projects have already begun. The first is IGCP Project 274 on "Coastal evolution in the Quaternary." Approved by the IGCP Board early this year, the new project aims to establish and explain local and global variations in the Quaternary evolution of coastal areas, including continental shelves. It will also create a useful basis of reference and comparison for teaching, research and prediction in the fields of coastal geology, management, resource extraction and hazards.

A second project began in late 1987 with support from the Commission of the European Communities and involving workers from France, Italy, Ireland, The Netherlands and the United Kingdom. This two-year project is studying past and future sea-level changes and their impacts on Europe. It is investigating recent sea-level trends using geological 
and archaeological data, and a compilation is being made of European tidal gauge data from the past 200 years. Attempts will be made to predict the timing and magnitude of future changes in sea level and to estimate variations in the frequency and magnitude of storm surges.

I'his project is also surveying parts of Europe already experiencing significant changes in sea level, and an assessment will be made of the potential impact on coastal areas due to future rises in sea level. It is hoped that this European project will, in the next decade, lead to a wider and more global effort, with adequate funding from national and international agencies, to provide a sounder basis for predicting future sea-level changes and thus for coping with the eventual consequences.

\section{A Comment on $\mathrm{CO}_{2}$ and Sea-Level Trends}

Though a study of the influence on sea level of a possibly increasing "greenhouse" $\mathrm{CO}_{2}$ effect was not among the initial aims of $1 \mathrm{GCP} 200$, this topic gained widespread attention a year or two after the project had started, with the catastrophic predictions of the U.S. Environmental Protection Agency. Although the initial warnings of a sealevel rise of 5 to $17 \mathrm{~cm}$ by the year 2000 and 56 to $34 \mathrm{~s} \mathrm{~cm}$ by 2100 were subsequently toned down by various authors eurrent estimates for the next century vary between 10 and $160 \mathrm{~cm}$ - they raised great international concern and premature alarm in the problem.

One point should be cleared up. Values of 1.0 to $1.5 \mathrm{~mm} / \mathrm{yr}$, which are often believed to correspond to the rate of the present "global" sea-level rise, are derived from averages from tidal gauge records (Fig. 4). These show seeular trends varying greatly from place to place, and they also reflect land movements, due to subsidence in most cases. In fact, only 138 of the records longer than $30-50$ years show rates of relative sea-level rise between 1.0 and $1.5 \mathrm{~mm} / \mathrm{yr}$. Some $38 \%$ show a rise greater than $1.5 \mathrm{~mm} / \mathrm{yr}, 20.5 \%$ a rise less than $1.0 \mathrm{~mm} / \mathrm{yr}$, and $28.5 \%$ a relative drop in sea-level.

Most of the long-term records come from the North Atlantic, where areas of glacio-isostatic uplift in canada and Fennoscandia are generally omitted from average calculations, whereas adjacent areas of glacio-isostatic subsidence, including most of the coasts of the U.S.A. and of Western Europe, are not. I' his helps to Dias current estimates towards an apparently higher average rise of sea level.

When long-term tectonic trends are deducted from the data, the average rise of sea level in the North Atlantic has only been 4 to $6 \mathrm{~cm}$ since the end of the last century. Moreover this rise occurred entirely between 1880 and 1950, when the global mean surface temperature increased about $0.0^{\circ} \mathrm{C}$ and a retreat of the ice front was reported for most midlatitude glaciers. In contrast, between 1950 and 1980 the average global mean temperature diminished sligntly in the Northern Hemisphere and was more or less steady on a world-wide scale (Jones et al., l9ø6), despite the increase in atmospheric $\mathrm{CO}_{2}$. Mid-latitude glaciers have remained almost stable or have started advancing again, and the average sea level, after deduction of local land movements, has remained almost stable or has dropped sligntly in the North Atlantic (Pirazzoli, in press). In short, no clear relationship between atmospneric $\mathrm{CO}_{2}$ content, climate and sea-level can yet be detected.

Although some indications of warming in the $1980 \mathrm{~s}$ are unequivocal (Kerr, 1988), a clear greenhouse-induced pattern is still not evident. It is widely agreed that a future increase in temperature would cause a rise in sea level, due to the thermal expansion of ocean water and the melting of continental ice. Estimated ranges of thermal expansion vary from 4 to $8 \mathrm{~cm}$ for an increase in temperature of 0.6 to $1.0^{\circ} \mathrm{C}$ (Wigley and Raper, 1987), to between 40 and more than $8 \mathrm{u} \mathrm{cm}$ for an increase of $3.5^{\circ} \mathrm{C}$ (Robin, 1986). A slignt increase in temperature may eause sensitive mid-latitude glaciers to melt, causing a sea-level rise of 8 to $25 \mathrm{~cm}$
(Meier, 1984), but the balance of the Antarctic and Greenland ice sheets would probably not be affected (Robin, ibid).

Those who ascribe the rises of $0.5^{\circ} \mathrm{C}$ in temperature and of $4-6 \mathrm{~cm}$ in sea level observed during the period $188 \mathrm{U}$ to $195 \mathrm{U}$ to "greenhouse" effects are troubled by the almost constant temperature and sea level observed between 1950 and 1980 (Jones et al., 1986). Far from fitting their models, this stability suggests rather that no distinct relation can yet be detected between the increase of $\mathrm{CO}_{2}$ and other so-called 'greenhouse' gases in the atmosphere, global mean temperature, and sea level.

Broecker (1975) and Wigley and Raper (1987) have assumed that a climatic oscillation would be superimposed on a longer term rising trend related to greenhouse effects. Thus, the rise in temperature could have been obscured during the last few decades by a short-lived negative trend, whose cause is not specified. The temperature evolution during the next few years will be crucial when testing these models.

Despite these uncertainties, the possibility that the atmospheric increase in $\mathrm{CO}_{2}$ and other gases could finally lead to a greenhouse increase in temperature and a rapid sea-level rise cannot be ignored, even if it is still not known precisely whether, when and to what extent it might occur. Further studies and a new multidisciplinary approach are certainly necessary in order to test assumptions and verify models.

\section{Acknowledgments}

The help and support of all those individuals and organizations who contributed in so many ways to the activities of the Project IGCP 200 are gratefully acknowledged.

Dr. Paolo A. Pirazzoli (16 rue de la Grange Batellière, 75009 Paris, France) is a Director of Research at the CNRS. With a background in civil engineering, his main research interests since 1970 have been in coastal geomorphology, neotectonics and problems related to past, present and future changes in sea level. Dr. Pirazzoli was the leader of IGCP Project 200 "Sealevel Correlation and Applications."

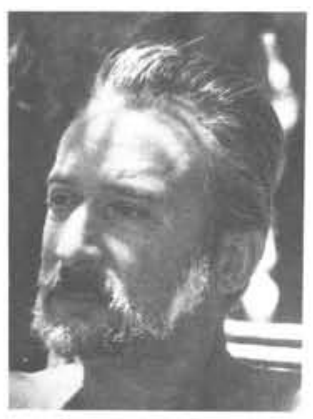

\section{References}

Bloom, A.L., 1967. Pleistocene shorelines: a new test of isostasy. Geological Society of America Bulletin, v. 78, no. 12, p. 1477-1494.

Bloom, A.L., (compiler), 1977. Atlas of Sea-Level Curves, Department of Geological Sciences, Cornell University, Ithaca, New York.

Broecker, w.S., 1975. Climatic change: are we on the brink of a pronounced global warming? Science, v. 189 , no. 4201 , p. $460-463$.

Burton, R., Kendall, C.G.C. and Lerche, I., 1987. Out of our depth: on the impossibility of fathoming eustasy from the stratigraphic record. Earth-Science Reviews, v. 24, no. 4, p. 237-277.

Carter, R.W.G. and Devoy, R.J.N. (eds.), 1987. The hydrodynamic and sedimentary consequences of sea-level change. Progress in Oceanography, v. 18, no. 1-4, p. 1-350.

Clark, J.A., Farrell, W.E. and Peltier, W.R., 1978. Global changes in postglacial sea level: a numerical calculation. Quaternary Research, v. 9 , no. 3 , p. 265-287.

Davies, P.J. and Montaggioni, L.F., 1985. Seminar A: Reef growth and sea-level change: the environmental signature. Proceedings of the 5th International Coral Reef Congress, Tahiti, v. 3, p. 477-515.

Devoy, R.J.N., (ed.), 1987. Sea Surface Studies: A Global View. Croom Helm, London, 649p.

Emiliani, C. and Shackleton, N.J., 1974. The Brunhes Epoch: isotopic paleotemperatures and geochronology. Science, v. 183 , no. 4124 , p. 511-514. 
Fairbridge, R.W., 196l. Eustatic changes in sea-level. Physics and Chemistry of the Earth, v. 4, p. 99-185.

Hopley, D. and Pirazzoli, P.A., (eds.), 1985. Symposium no. 1: Late Quaternary and present sea-level changes: magnitude, causes, future applications. Proceedings of the 5 th International Coral Reef Congress, Tahiti, v. 3, p. 77-218.

Intergovernmental Oceanographic Commission (IOC), 1985. Manual on Sea Level Measurement and Interpretation. Manuals and Guides, no. 14 , Unesco, Paris, 86 p.

Jones, P.D., Wiglev, T.M.L. and Wright, P.B., 1986. Global temperature variations between 1861 and 1984 . Nature, v. 322 , no. 6078 , p. $430-434$.

Sawana, T. and Pirazzoli, P.A., 1985. Holocene coastline changes and seismic uplift in Okinawa Island, the Ryukyus, Japan. Zeitschrift für Geomorphologie, Supplementband 57, p. 11-31.

Kerr, R.A., 1988. The weather in the wake of El Nino. Science, v. 240 , no. 4854 , p. 883 .

Heier, I.F., 1984. Contribution of small glaciers to global sea level. Science, v. 226 , no. 4681 , p. 1418-1421.

Mörner, N.A., 1976. Eustasy and geoid changes. Journal of Geology, v. 84 , no. 2 , p. $123-151$.

Pirazzoli, P.A., 1976. Les Variations du Niveau Marin Depuis 2000 Ans. Mémoires du Laboratoire de Géomorphologie de l'Ecole Pratique des Hautes Etudes, Dinard, France, no. 30, p. 1-421.

Pirazzoli, P.A., (ed.), 1987a. IGCP Project 200 - Summary Final Report. CNiSS-Intergéo, Paris, 87p. (Available from the writer of this paper).

Pirazzoli, P.A., 1987b. Recent sea-level changes and related engineering problems in the lagoon of Venice (Italy). Progress in Oceanography, v. 18, p. 323-346.

Pirazzoli, P.A., (in press). Recent sea-level changes in the North Atlantic. In: Late Quaternary Sea-Level Correlation and Applications. Proceedings of the NATS Advanced Study Institute, Halifax, Canada, 19-30 July 1987, Reidel.

Pjrazzoli, P.A. and Grant, D.R., 1987. Lithospheric deformation deduced from ancient shorelines. In: Kasahara, K. (ed.), Recent
Plate "Tovements and Deformation. American Geophysical Union Geodynamics Series, v. 20, D. 67-72.

Pirazzoli, P.A. and Suter, J.R. (eds.), 1986, Late Quaternary sealevel changes and coastal evolution. Journal of Coastal Research, Special lssue, no. 1, p. 1-98.

Pirazzoli, P.A. Schnack, E.J. and Rabassa, J. (eds.), 1985. Selected papers of the international symposium on Late Quaternary sealevel changes and coastal evolution ( Tar del Plata, 30 September 3 October 1984). Quaternary of South America and Antarctic Peninsula, 3alkems, 3, p. 161-226.

Plassche, O. van de (ed.), 1986. Sea-Level Research: a ilanual for the Collection and Evaluation of Data. Geo Fooks, Norwich, $618 \mathrm{p}$.

Pugh, D.T., 1987. Tides, Surges and Mean Sea Level. John wiley, $472 \mathrm{p}$.

Qin, Y. and Zhao, S. (eds.), 1987. Late Quaternary Sea-Level Changes. China Ocean Press, Beijing, $251 \mathrm{p}$.

Raban, A. (ed.), 1988. Archaeology of Coastal Changes. BAR International Series no. 404, Dxford, $252 \mathrm{p}$.

Zobin, G. de Q., 1986. Changing the sea level. In: Bolin, B. et al. (eds.), The Greenhouse Effect, Climatic Change and Ecosystems. A Synthesis of Present Knowledge. SCOPE, v. 29, John Wiley, p. 323-359.

Shennan, 1. and Pirazzoli, P.A. (compilers), 1987. Directory of SeaLevel Research. Second edition. Geologiska Inst., Stockholm University, 92p. (Available from the aut hor of this paper.)

Shepard, F.P., 1964. Sea level changes in the past 6000 years, Possible archaeological sisnificance. Science, v. 143 , no. 3606 , p. 574576.

Tooley, M.J. and Shennan, I. (eds.), 1987. Sea-Level Changes. Institute of British Geographers Special Publication v. 20. Basil 3lackNell, Oxford, 397p.

Walcott, R.I., 1972. Past sea levels, eustasy and deformation of the Earth. Quaternary Research, v. 2, no. 1, p. 1-14.

vigley, T.M.L. and zaper, S.C.B., 1987. Thermal expansion of sea water associated with global warming. Nature, v. 330 , no. 6144 , ?. $127-131$.

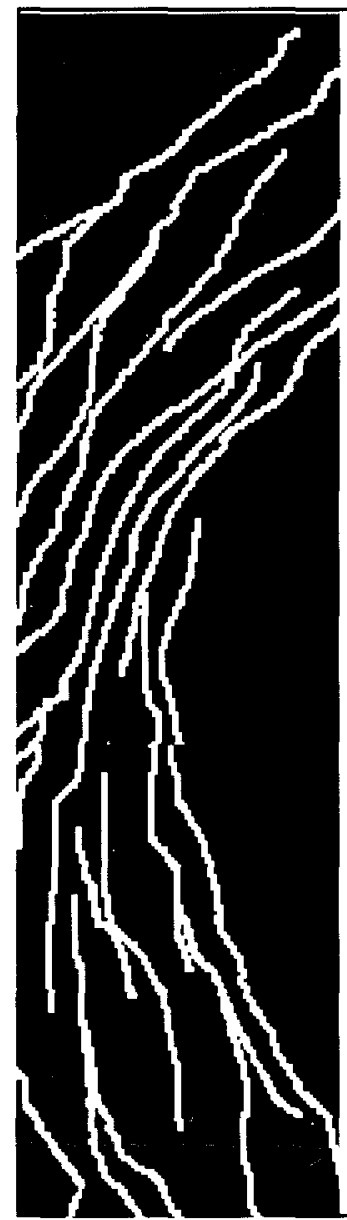

\section{Mafic Dyke Swarms}

\section{Edited by H.C. Halls and W.F. Fahrig}

Just released by the Geological Association of Canada

A collection of papers based on the proceedings of an international conference

$$
41 \text { papers } \quad 106 \text { authors } 503 \text { pages }
$$

Mechanics, Thermal Regime and Magma Flow Characteristics

Geochemistry and Radiometric age dating

Aeromagnetic Interpretation and Paleomagnetism

Tectonics and the Wilson Cycle

Mafic Dykes in Precambrian Shields: A survey of the Global Data Base

ORDER FORM: Please send me copies of Mafic Dyke Swarms @ \$65 (GAC Members) or \$79 (non-members) plus \$3 shipping per copy

VISA or Mastercard \# Exp. Name: Signature:

Address:

Or send cheque or money order payable to Geological Association of Canada; Mail orders to GAC Publications, Geological Association of Canada, Department of Earth Sciences, Memorial University of Newfoundland, St. John's, NF, A1B 3X5, Canada. Payment must accompany order in Canadian funds or equivalent. 